\title{
Diagnosis of the Use of Information Technology and Communication in the Dynamics of the Educational Process of Higher Education in Ecuador
}

\author{
Javier Guaña-Moya $^{1+}$, María Pérez-Fabara² ${ }^{2}$ Edwin Quinatoa-Arequipa ${ }^{3}$ and Mónica del Rocío \\ Sánchez-Charro 4 \\ ${ }^{1}$ Pontificia Universidad Católica del Ecuador / Facultad de Ingeniería, Ecuador \\ ${ }^{2}$ Universidad Central del Ecuador / Facultad de Ingeniería Ciencias Físicas y Matemática, Ecuador \\ ${ }^{3}$ Universidad Técnica del Cotopaxi / Facultad de Ciencias de la Ingeniería y Aplicadas, Ecuador \\ ${ }^{4}$ Universidad Central del Ecuador / Facultad de Ingeniería Ciencias Físicas y Matemática, Ecuador
}

\begin{abstract}
Higher education has different academic offerings and as a target the training of professionals in different areas, these proposals aim to achieve a high performance through the applications of information and communication technologies (TIC), which allow to improve the educational process; So that $81 \%$ of students do not apply virtual environments and do not know e-learning resources, which specifies that $79 \%$ of teachers do not work with online applications, while $21 \%$ apply these processes, Thus demonstrating that teachers teach their professors without TIC support and without the use of e-learning resources, so the technological progress in education is not encouraged and it is evident that $89 \%$ of teachers teach their classes theoretically, $8 \%$ link theory to practice and $3 \%$ use supports in virtual resources.
\end{abstract}

Keywords: Education, e-learning, learning, technological, research, ecuador

\section{Introduction}

The platforms of virtual environments of teaching - learning (EVEA), are considered as spaces with virtual access, therefore a virtual environment must allow to share the information, knowledge and experiences with the other participants in a synchronous and asynchronous way, which is considered by [1], as the existence of interactivity as the basis of any learning process, based on technologies or TIC.

These environments have been taken by several authors such as [2], which analyse the development of new teaching methodologies and the analysis of new strategies for university teachers based on online learning.

[3], describe that technological environments are fundamental pillars in the implementation of EVEA, however, [4], affirms that, an EVEA is a set of computer and telematics facilities for the exchange of information in which educational processes are developed, for which, [5], evidences the development of cognitive interactivity in EVEA, whereas, [6], highlights the importance of the collaboration and cooperation developed within these EVEA.

From these meanings about the virtual learning teaching environments, [7], will consider as the work spaces where experiences are generated sensations based on network technology, web support and e-learning technologies, thus giving a better development in the work circle by teachers and students. Therefore, Information and Communication Technologies (TIC) are not a panacea or magic formula, but they can improve the lives of all the inhabitants of the planet, for that reason they have tools to reach the objectives of

\footnotetext{
+ Corresponding author. Javier Guaña-Moya. Tel.: + 593995000484.

E-mail address: eguana953@ @uce.edu.ec.
} 
the new millennium, obtain instruments that will allow advance in new technological processes and be the necessary means to spread knowledge and facilitate mutual understanding through the internet.

Computer science, telecommunications and virtual education have benefited from new e-learning applications, which has allowed the generation of new digital consumers. All this technological development has allowed the advancement of the computer science and the development of the countries, nevertheless, there are still countries that have not used efficiently the technological development for the education, [8].

Because of the above, [9], states that there is an isolated use of TIC in educational processes, since there is no evidence of the existence of a didactic process, while [10], describe that TIC can offer the necessary foundations of how to guide the teaching practice in the execution of technological applications.

Therefore, the objective of this article is to diagnose the current state of the use of TIC, in the dynamics of the educational processes of higher education, in the first levels of face-to-face, blended learning and distance learning in the Province of Sucumbíos, Lago Agrio Canton.

\section{Materials and Methods}

The research carried out and everything presented in this article was carried out in the canton of Lago Agrio, Province of Sucumbíos - Ecuador, and the results obtained were obtained through surveys conducted with teachers and students of the first levels of higher education of the different existing universities in said canton, said results allowed generating criteria adopted in the dynamics of the educational processes of Ecuadorian education.

As described above, the authors took as a basis the subjects oriented to TIC, for the analysis and diagnosis of the dynamics of educational processes, therefore an analysis was carried out during the years 2015 - 2016, which consisted in generating surveys at 350 students of the first semester and 50 teachers who teach subjects related to TIC in different careers and universities.

Taking as an observation the formative activities that are offered in Ecuadorian higher education and taught in the different modalities of study.

The essential indicators for the process of analysis and diagnosis in the present investigation of both teachers and students were the following:

Knowledge about virtual education.

- Use of EVEA, TIC and its applications.

- Technological resources of virtual education and tools that are used in the teaching - learning processes in the different careers.

\section{Results}

\subsection{Instrument $\mathbf{N}^{0} 1$. surveys Directed to Students}

Instrument No. 1 was addressed to university professionals and questions related to: technological advancement, TIC, EVEA, virtual platforms, use of technological resources in virtual education, media and tools used by teachers to teach were taken into account. This instrument was applied to the first levels of higher education, in the Province of Sucumbíos, Cantón Lago Agrio, Ecuador

The applied instrument exhibited the following results:

TIC are known in all areas, which evidenced that in educational processes $83 \%$ of respondents answered that they know what TIC are, while in EVEA the majority of students (81\%) do not know what ICTs are. virtual environments and resources, as well as the advantages of virtual education for teaching - learning processes (T/L).

A large percentage of the students surveyed are unaware that they are virtual platforms, this is evidenced by $79 \%$ of negative responses and $21 \%$ know that they have been updated in the computer field or on their own initiative. 
Teachers in teaching their chairs without TIC support and without the use of technological resources, do not promote educational improvement, so $80 \%$ of students do not know the virtual platforms that exist for the better development of $\mathrm{T} / \mathrm{L}$ processes.

Regarding the form of teaching, it can be said that $70 \%$ of the students surveyed indicate that teachers teach theoretically, $8 \%$ say that they link theory with practice and a minority percentage (3\%) say that in their classes they use supports in virtual resources.

In the use of resources and technological tools used by teachers, it can be described that the most used is email with $86 \%$, followed by forums $10 \%$ and it can be shown that $4 \%$ say that teachers use web applications for support of the meetings in their different subjects.

About the teaching methods used by teachers, $76.2 \%$ indicate that the most used medium is the blackboard, and the least used is the specialized software with $13.8 \%$, it should be noted that $10 \%$ say they use technology (Internet, projector, etc.).

The evaluation processes carried out by teachers are traditional and not supported by TIC, so the highest percentage of students $(93 \%)$ indicates that the most widely used evaluation process is written, while a minority group it specifies that it is done in different ways (7\%).

In one of the questions asked about what type of study would you prefer for your professional training; the answer was that $78 \%$ would like to study face-to-face, $20 \%$ do not know and $2 \%$ specify that they would like to study in virtual or remote form.

\subsection{Instrument No. 2. Surveys Addressed to Teachers}

For the analysis of the instrument No. 2, teachers who teach classes at the first levels of face-to-face, blended learning and distance classes were taken into account, therefore the questions are related to: years of service in higher education, professional training, technological advance, TIC, EVEA, virtual platforms, training of university professionals in Virtual Environments, bibliographic material used in classes, use of technological resources, as well as the materials, tools and means used by teachers to teach their subjects.

The instrument made displayed the following results:

Regarding the experience of teachers in higher education, it can be seen that most of them have worked for 1 to 3 years in higher education, according to the $85 \%$ who gave the survey and $15 \%$ who have experience in higher education. 3 to 10 years.

Based on the academic preparation, $65 \%$ of teachers have fourth level studies (master's degree), while $35 \%$ have third level degrees, this is because there are some areas that do not have a degree in the higher education, among others.

Regarding the knowledge of the EVEA and virtual education resources, it can be identified that $75 \%$ of respondents do not know or have not used these virtual resources of T/L, while $25 \%$ answered that they do know or used.

Another important point is the use of virtual platforms, in which $85 \%$ of responses are negative in use, while $15 \%$ know and use, since they have been updated in the computer field or on their own initiative.

Regarding the way of teaching teachers' classes, $65 \%$ of respondents indicate that they teach the subject in a participative way and link the theory with practice and $35 \%$ say that their classes are not theoretical, likewise it is evident that do not use virtual supports or e-learning resources in the T/L process.

Regarding the use of technological means, $30 \%$ of teachers surveyed describe that they use email to send information to students, but this is not done frequently, while the rest (70\%) of respondents describe that they do not use any computer applications for the teaching processes, so they do not use technological tools as support in the educational process, which is why it is not possible to achieve a better development of the different subjects.

The $30 \%$ respondents indicate that they use the projector as technological support, while $60 \%$ use the blackboard and $10 \%$ use specialized software. 
In the different processes of $\mathrm{T} / \mathrm{L}, 50 \%$ respond that the vast majority use the lecture, followed by $25 \%$ say they do group work and 5\% of teachers surveyed say they work with debates, exhibitions and face-toface forums in class.

Regarding the evaluation, $70 \%$ indicates that the evaluation process most used by teachers is written exams, $25 \%$ say they are oral, you can also see that 5\% take as an option the exams through the internet or Online (Teacher of the IT area). The least used by teachers to support students are forums or online discussions, this is verified with $20 \%$, while $50 \%$ of respondents say they use tutorials and $30 \%$ call that there are other means to Support the student in their learning process.

Regarding the bibliographic sources used by teachers for the best educational development, it is evident that books in physical form are the most used means by teachers with 70\%, 20\% think that the information that exists on the web is valid and use digital media, while $10 \%$ of teachers use their own brochures or guides and do not use research theses, scientific articles, etc.

\section{Conclusions}

From the analysis and diagnosis, it was evidenced that:

- In the research carried out, it is evident that there is a lack of knowledge on the part of the students in the support that the EVEA presents and the technological resources in face-to-face, blended and virtual education; so the analysis of the data taken describe that $78 \%$ would like to study in person to learn efficiently, $20 \%$ do not know and $2 \%$ specify that they would like to study at a distance but do not know how to do it, describing in this way the partial ignorance of the benefits provided by technological applications and ICT, in the different types of study that currently exist in higher education.

- The constant technological update of the virtual resources, allows to acquire new knowledge in the EVEA, and since there is no such update, the teachers give their chairs without the support of virtual environments, this does not allow a better development in the technological advance in education, therefore, it can be said that students and teachers do not know the virtual platforms do not improve the teaching - learning processes, this is evident with $70 \%$ of respondents ignore virtual platforms and their uses in education, while $20 \%$ do not know the Moodle platform, and $10 \%$ do not know or have worked on any virtual platform for the $\mathrm{E} / \mathrm{A}$ processes.

- Teachers, when teaching their chairs without the support of the Technologies, do not promote technological advancement in education, this is evident since $80 \%$ of teachers teach their classes in a masterly way without relying on ICT, this does not allow to potentiate skills and skills of each student in the different learning areas, achieving inefficiency in the search and interpretation of information; Therefore, self-education is not encouraged in students and teachers, for this purpose, the development of the students' professional and technological capacities must be strengthened through the EVEA.

- According to the analysis of the instruments of the present investigation, it has been demonstrated that the current use of technological resources in the Lago Agrio Canton has not managed to encourage, stimulate, or motivate students about ICT and its tools, which does not allow the search and constant investigation of general and particular information on the different topics of interest, which is why it should generate new processes of improvements in education and provide students with new tools, techniques, methodologies and teaching - learning strategies for better educational processes.

- In the province of Sucumbíos, online or virtual study has not been encouraged, which is why many teachers and students do not know what EVEAs are, as well as the different applications that occur in virtual platforms, which is why they do not know the benefits that provide educational processes in education e-learning, b-learning, m-learning, among others, which is why ignorance of technological advances in education, does not allow the best educational development, so teachers continue imparting their classes theoretically, through lectures and this does not allow linking the 
theory with practice, or get a better development through the tools and means offered by the computer.

- On the other hand, it was seen that the methods, techniques and methodologies used in the development of learning and evaluation are not in line with the new educational processes, so the evaluation process most used by teachers is written and on paper, this is due to the ignorance of the use of forums, debates and online exams, thus achieving the demotivation of the student and the lack of interest in the search for information and the constant improvement in all actors involved in education.

\section{References}

[1] López, Y. A. B., Constante, G. F. G., \& Black, L. G. C. (2017). Efectos del consumo digital en la Educación Latinoamericana. Revista Publicando, 4(11 (1)), 690-703.

[2] Moya, E. J. G., Escobar, A. G. A., \& Remache, K. J. O. (2015). Caracterización del consumidor digital ecuatoriano. Revista Publicando, Vol. 2, Núm. 5, pp. 226-242.

[3] De Benito, B. \& Salinas, J. (2008). Los entornos tecnológicos en la universidad. Pixel-Bit. Revista de Medios y Educación, Núm. 32, marzo, pp. 83-101.

[4] Mestre, U. y col. (2007). Entornos Virtuales de Enseñanza Aprendizaje. Monografía. Centro de estudios de Didáctica Universitaria. Universidad Territorial de Las Tunas. Editorial Universitaria. MES.

[5] Encarnación, E. (2010), El desarrollo de la interactividad cognitiva en entornos virtuales de enseñanza aprendizaje en el ámbito universitario. Tesis en opción al grado científico de Doctor en Ciencias Pedagógicas. Universidad de Camagüey. Cuba.

[6] García, O. (2010), Concepción pedagógica de un entorno virtual de enseñanza aprendizaje desarrollador para la formación de profesores. Tesis en opción al grado científico de Doctor en Ciencias Pedagógicas. Universidad de Ciencias Pedagógicas "Frank País García". Santiago de Cuba.

[7] Guaña-Moya, E. J., del Rosario Llumiquinga-Quispe, S., \& Ortiz-Remache, K. J. (2015). Caracterización de entornos virtuales de enseñanza aprendizaje (EVEA) en la educación virtual. Ciencias Holguín, Vol. 21, Núm. 4, pp. 71-86.

[8] Guaña-Moya, E. J., Quinatoa-Arequipa, E., \& Augusta-Pérez, M. (2017). Tendencias del uso de las tecnologías y conducta del consumidor tecnológico. Ciencias Holguín, Vol. 23, Núm. 2, pp. 15-30.

[9] Martínez, L. R., Navarro, R. E., \& Rodríguez, S. F. (2013). El blended-learning en la formación docente, análisis del diplomado PROFORDEMS en México. In XXI Encuentro Internacional de Educación a Distancia.

[10] Moya, E. J. G., Herrera, D. G. G., \& Arequipa, E. E. Q. (2017). Utopía o realidad de aplicaciones informáticas en la educación. Caso Universidad Ecuatoriana. Revista Publicando, 3(9), 119-137. 